\title{
IMPROVEMENT OF XYLANASE PRODUCTION BY COCHLIOBOLUS SATIVUS IN SOLID STATE FERMENTATION
}

\author{
Yasser Bakri; Mohammed Jawhar; Mohammed Imad Eddin Arabi
}

Department of Molecular Biology and Biotechnology, AECS, Damascus, Syria.

Submitted: June 11, 2007; Returned to authors for corrections: October 04, 2007; Approved: July 14, 2008.

\begin{abstract}
The xylanase production by Cochliobolus sativus strain Cs6 was improved under solid state fermentation (SSF). High xylanase activity $(1079 \mathrm{U} / \mathrm{g})$ was obtained when wheat straw was used after 8 days of incubation. Combinations of sodium nitrate with peptone or yeast extract resulted in an increased xylanase production (1543 and $1483 \mathrm{U} / \mathrm{g}$, respectively). The Cs6 strain grown in SSF in a simple medium, proved to be a promising microorganism for xylanase production.
\end{abstract}

Key-words: Cochliobolus sativus, xylanase, solid-state fermentation

\section{INTRODUCTION}

Xylanase has attracted special attention due to its potential applications in many processing industries $(16,21)$. The use of purified xylan as a substrate for bioconversion into xylanase increases the cost of enzyme production. Consequently, for commercial applications, there have been attempts to develop a bioprocess to produce xylanase in high quantities from simple and inexpensive substrates. Abundantly available lignocellulosic residues are an obvious choice as substrate (21).

Although xylanase from eubacteria and archaebacteria have considerable higher temperature optima and stability than those of fungi, the amount of enzyme produced by these bacteria is comparatively lower than that produced by fungi. In general, the level of xylanase in fungal culture is typically much higher than those from yeasts and bacteria (20). A filamentous fungus, particularly Cochliobolus sp. is a useful producer of xylanases from an industrial point of view. Several enzymatic activities were investigated in isolates of the fungus Cochliobolus sativus, the causal agent of barley spot blotch disease, such as cellulose-hydrolysing enzymes (14), endo-1, 4- $\beta$-xylanase (18) and endopolygalacturonase (6). However, enzyme production is related to the type and concentrations of carbon and nitrogen sources $(11,13)$. In the present study, we report the effects of different substrates on xylanase production by the newly Cochliobolus sativus strain Cs6 under solid state fermentation (SSF).

The strain of C. sativus Cs6 is described by Arabi and Jawhar (3). It was isolated from infected barley leaves showing spot blotch symptoms, and screened among 117 isolates as the best xylanase producer in submerged culture on different carbon sources. The isolate was grown separately in $9 \mathrm{~cm}$ Petri dishes containing potato dextrose agar (PDA, DIFCO, Detroit, MI. USA) and incubated for 10 days, at $22 \pm 1{ }^{\circ} \mathrm{C}$ in the dark to allow mycelia growth.

Enzyme production by the selected strain was carried out in $250 \mathrm{ml}$ Erlenmeyer flasks containing $5 \mathrm{~g}$ of solid substrate and nutrients (based on $100 \mathrm{ml}$ of liquid medium) plus distilled water to adjust the moisture content to $80 \%$. The fermentation medium consisted of: $(\mathrm{g} / \mathrm{L}) \mathrm{Na}_{2} \mathrm{HPO}_{4} .2 \mathrm{H}_{2} \mathrm{O} 10 ; \mathrm{KCl} 0.5 ; \mathrm{MgSO}_{4} .7 \mathrm{H}_{2} \mathrm{O}$ 0.15 , and $\mathrm{NaNO}_{3} 6$, as a nitrogen source. The influences of different lignocellulosic materials (wheat bran, corn hulles, and wheat straw) and the incubation time on xylanase production were tested (Fig. 1). The combinations of sodium nitrate with one of other nitrogen sources as peptone, yeast extract, ammonium nitrate, ammonium chloride, ammonium sulfate, urea, and potassium nitrate were also investigated in the this work. The $\mathrm{pH}$ was adjusted to 4.5 before sterilization. This $\mathrm{pH}$ value was found to be the optimal one for xylanase production in our experiments (data not included). Fresh fungal spores have been

*Corresponding Author. Mailing address: Department of Molecular Biology and Biotechnology, AECS, P. O. Box 6091, Damascus, Syria. E-mail: miaraabi@aec.org.sy 
used as inoculums and $1 \mathrm{~mL}$ spore suspension (containing around $10^{6}$ spores $/ \mathrm{mL}$ ) was added to sterilized medium and incubated at $30^{\circ} \mathrm{C}$.

Flasks were removed after cultivation and the enzyme was extracted by adding distilled water containing $0.1 \%$ Triton $\mathrm{x} 100$ to make the volume in flask equivalent to $100 \mathrm{~mL}$. The flasks contents were stirred for 1.5 hours on a magnetic stirrer. The clear supernatant was obtained by centrifugation $(5000 \mathrm{x}$ g for $15 \mathrm{~min}$ ) followed by filtration (Whatman no. 1. paper).

Xylanase activity was assayed by the optimized method described by Bailey et al. (4), using 1\% birchwood xylan as substrate. The solution of xylan and the enzyme at appropriate dilution were incubated at $55^{\circ} \mathrm{C}$ for 5 minutes and the reducing sugars were determined by the dinitrosalicylic acid procedure (17), with xylose as standard. The released xylose was measured spectrophotometrically at $540 \mathrm{~nm}$. One unit (U) of enzyme activity is defined as the amount of enzyme releasing $1 \mu \mathrm{mol}$ xylose $/ \mathrm{ml}$ per minute under the described assay conditions.

The experiments were repeated twice, and all the results represent mean values. Statistical analyses were performed using the STAT-ITCF program (2) to test for differences in xylanase production among different agricultural wastes tested

Fig. 1 shows that the highest xylanase production (1079 U/ g) was obtained on wheat straw after 8 days of incubation, whereas, wheat bran and corn hulles exhibited low activities. These results might be attributed to the fact that the presence of more available nitrogen increases both mycelium grows and its activity. Moreover, Haltrich et al. (14) reported that the ratio of cellulose to xylan of the growth substrate is important for the

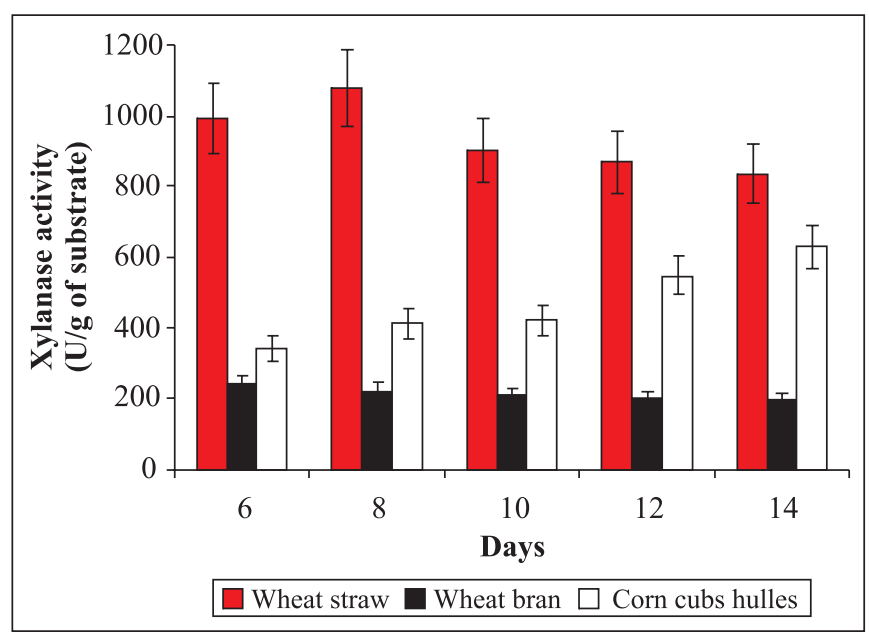

Figure 1. Effect of different lignocelluloses on xylanase production from Cochliobolus sativus in solid-state fermentation after 6 to 14 days of culture in the medium with $0.6 \% \mathrm{NaNO} 3$ as nitrogen source and incubated at $30^{\circ} \mathrm{C}$. production of xylanase. However, Emami and Hack, $(2001 ; 2002)$ $(9,10)$ postulated two genes XYN11A and XYN11B are responsible for xylanase production in $C$. sativus.

When a number of nitrogen sources were tested using wheat straw as a substrate, the results (Table 1) showed that the combinations of peptone or yeast extract with sodium nitrate resulted in increased xylanase production after 8 days of culture by $26 \%(1543 \mathrm{U} / \mathrm{g})$ and $21 \%(1483 \mathrm{U} / \mathrm{g})$, respectively, as compared to the fermentations in which these compounds were not used. These results are in agreement to those reported in the literature where fungi produced higher xylanase activities on similar organic nitrogen sources $(1,5,22)$. Yeast extract has an important role in enzyme synthesis, probably because this complex nitrogen source contains elements that are necessary for the metabolism of fungus (16). Moreover, Lemos et al. (16) reported that the ability of a cell to utilize a particular compound depends in the first place on the genetic ability of the organism to synthesize the requisite enzyme, and in the second place on its capacity to respond to induction.

Although quantitative comparison of xylanase activities reported in literature is not always possible because no strand enzyme substrate has been adopted yet, the yield of xylanase productivity from C. sativus observed in this work were approx 3 folds higher than optimum productivities reported in the literature for some microorganisms grown in SSF (Table 2).

The present study reveals that $C s 6$ strain is very promising as it produced a high level of xylanase under improved conditions. Moreover, combinations of peptone or yeast extract with sodium nitrate resulted in an increased xylanase production compared to the fermentations in which these compounds were not used. As a consequence, production of xylanase by $C$. sativus strain Cs 6 could be improved by a further optimization of the medium and culture conditions.

Table 1. Effect of sodium nitrate combined with $0.5 \mathrm{~g}$ of nitrogen sources on xylanase production after 8 days of culture using $5 \mathrm{~g}$ of wheat straw as a substrate.

\begin{tabular}{cc}
\hline Nitrogen sources & Xylanase $(\mathrm{U} / \mathrm{g})$ \\
\hline $\mathrm{NaNO}_{3}$ & $076 \mathrm{~b}$ \\
$\mathrm{NaNO}_{3}+$ peptone & $1543 \mathrm{a}$ \\
$\mathrm{NaNO}_{3}+$ yeast extract & $1483 \mathrm{a}$ \\
$\mathrm{NaNO}_{3}+\mathrm{NH}_{4} \mathrm{NO}_{3}$ & $928 \mathrm{c}$ \\
$\mathrm{NaNO}_{3}+\mathrm{NH}_{4} \mathrm{Cl}$ & $791 \mathrm{~d}$ \\
$\mathrm{NaNO}_{3}+\left(\mathrm{NH}_{4}\right)_{2} \mathrm{SO}_{4}$ & $922 \mathrm{~d}$ \\
$\mathrm{NaNO}_{3}+\mathrm{Urea}_{3}$ & $1033 \mathrm{~b}$ \\
$\mathrm{NaNO}_{3}+\mathrm{KNO}_{3}$ & $1040 \mathrm{~b}$ \\
\hline
\end{tabular}

Values followed by different letters differ significantly at $p=0.05$ (Newman-Keuls test). 
Bakri, Y. et al.

Table 2. Optimum xylanase activities produced by filamentous fungi grown in SSF

\begin{tabular}{lcccc}
\hline Microorganism & Substrate & $\begin{array}{c}\text { Cultivation } \\
\text { conditions }\end{array}$ & $\begin{array}{c}\text { Activity } \\
\text { (IU/g of substrate) }\end{array}$ & Reference \\
\hline Allescheria terrestris & Beet pulp & $45^{\circ} \mathrm{C}, 3 \mathrm{~d}$ & 28.3 & Grajek, 1987(12) \\
Aspergillus niger USMA11 & Palm cake & $30^{\circ} \mathrm{C}, 7 \mathrm{~d}$ & 33.99 & Kheng and Omar, 2005(15) \\
Chaetomium cellulolytium ATCC32319 & Wheat straw & $37^{\circ} \mathrm{C}, 10 \mathrm{~d}$ & 580 & Dubeau et al., 1986(8) \\
Cochliobulus sativus & Wheat straw & $30^{\circ} \mathrm{C}, 8 \mathrm{~d}$ & 1543 & This work \\
$\begin{array}{l}\text { Penicillum capsulatum } \\
\text { Trichoderma harzianum } \text { Rifai }\end{array}$ & Beet pulp+ wheat bran & $30^{\circ} \mathrm{C}, 9 \mathrm{~d}$ & 280 & Considine et al., 1989(7) \\
& Sugarcane bagasse & $30^{\circ} \mathrm{C}, 7 \mathrm{~d}$ & 82 & Rezende et al., 2002(19) \\
\hline
\end{tabular}

\section{ACKNOWLEDGMENTS}

Authors are gratefully acknowledged to the Director General of AECS and the Head of Biotechnology Department for their help throughout the period of this research.

\section{RESUMO}

\section{Melhoramento da produção de xilanase por Cochliobolus sativus por fermentação em estado sólido}

A produção de xilanase por Cochliobolus sativus cepa Cs6 SATIVUS por fermentação em estado sólido (SSF) foi melhorada. Com o emprego de palha de trigo, obteve-se elevada atividade de xilanase (1079 U/g) após 8 dias de incubação. Combinações de nitrato de sódio com peptona ou extrato de levedura aumentaram a produção de xilanase (1543 e $1483 \mathrm{U} / \mathrm{g}$, respectivamente). Comprovou-se que a cepa Cs6, cultivada em SSF em meio simples, é um microrganismo promissor para produção de xilanase.

Palavras-chave: Cochliobolus sativus, xilanase, fermentação em estado sólido

\section{REFERENCES}

1. Abdel-Star, M.A.; EL-Said, A.H.M. (2001). Xylan-decomposing fungi and xylanolytic activity in agricultural and industrial wastes. Intern. Biodeterior. Biodegrad., 47, 15-21.

2. Anonymous (1988). STAT-ITCF, Programme, MICROSTA, ECOSOFT, $2^{\text {nd }}$ Ver. Institut Technique des Cereals et des Fourrages Paris, France.

3. Arabi, M.I.E.; Jawhar, M. (2007). Molecular and pathogenic variation identified among isolates of Cochliobolus sativus. Aust. Plant Pathol., $36,17-21$.

4. Bailey, M.J.; Baily, P.; Poutanen, R. (1992). Interlaboratory testing of methods for assay of xylanase activity. J. Biotechnol., 23, 257-270.

5. Bakri, Y.; Jacques, P.; Thonart, P. (2003). Xylanase production by Penicillium canescens $10-10 \mathrm{c}$ in solid-state fermentation. Appl. Biochem. Biotech., 105-108, 737-748.

6. Clay, R.P.; Bergmann, C.W.; Fulier, M.S. (1997). Isolation and characterization of an Endopolygalacturonase from Cochliobolus sativus and a cytological study of fungal penetration of barley. Phytopathol., 87, 1148-1159.
7. Considine, P.J.; Buckley, R.J.; Griffin, T.O.; Tuohy, M.G.: Coughlan, M.P. (1989). A simple and inexpensive method of solid-state cultivation. Biotechnol. Tech., 3, 85-90.

8. Dubeau, H.; Chahal, D.S.; Ishaque, M. (1986) Production of xylanases by Chaetomium cellulyticum during growth on lignocelluloses. Biotechnol. Lett., 8, 445-448.

9. Emami, K.; Hack, E. (2001). Characterization of xylanase gene from Cochliobolus sativus and its expression. Mycol. Res., 105, 352-359.

10. Emami, K.; Hack, E. (2002). Conservation of XYN11A and XYN11B Xylanase Genes in Bipolaris sorghicola, Cochliobolus sativus, Cochliobolus heterostrophus, and Cochliobolus spicifer. Curr. Microbiol., 45, 303-306.

11. Geimba, M.P.; Riffel A.; Agostini, V.; Bandelli, A. (1999). Characterization of cellulose-hydrolysing enzymes from the fungus Bipolaris sorokiniana. J. Sci. Food Agric., 79, 1849-1854.

12. Grajek, W. (1987). Production of D-xylanses by thermophilic fungi using different methods of culture. Biotechnol. Lett., 9, 353-356.

13. Guimaraes, L.H.S.; Nogueira, P.S.; Michelin, M.; Rizzatti, A.C.S.; Sandrim, V.C.; Zanoela, F.F.; Aquino, A.C.M.M.; Junior, A.B.; Polizeli, M.L.T.M. (2006) Screening of filamentous fungi for production of enzymes of biotechnological interest. Braz. J. Microbiol., 37, 474-480.

14. Haltrich, D.; Nidetzky, B.; Kulbe, K.D.; Steiner, W.; Zupaneie, S. (1996). Production of fungal xylanases. Biores. Technol., 58, 137-161.

15. Kheng, P.P.; Omar, I.C. (2005). Xylanase production by a local fungal isolate, Aspergillus niger USM AI 1 via solid state fermentation using palm kernel cake (PKC) as substrate. Songklanakarin J. Sci. Technol., 17, 325-336.

16. Lemos, J.L.S.; Fontes, M.C.A.; Pereire, N.J. (2001). Xylanase production by Aspergillus awamori in solid-state fermentation and influence of different nitrogen sources. Appl. Biochem. Biotechnol., 91-93, 681-689.

17. Miller, G.L. (1959). Use of dinitrosalicylic acid reagent for determination of reducing sugars. Ann. Chem., 31, 426-428.

18. Peltonen, S. (1995).Comparison of xylanase production by fungal pathogens of barley with special reference to Bipolaris sorokiniana. Mycol. Res., 6, 717-723.22.

19. Rezende, M.I.; Barbosa, A.M.; Vasconcelos, A.F.D.; Endo, A.S. (2002). Xylanse production by Trichoderma harzianum rifai by solid state fermentation on sugarcane bagasse. Braz. J. Microbiol., 33, 67-72.

20. Singh, S.; Pillay, B.; Prior, B.A. (2003). Thermal stability of $\beta$ xylanase produced by different Thermomyces lanuginosus strains. Enzyme Microb. Technol., 26, 502-208.

21. Wong, K.K.Y.; James, C.S.; Campion, S.H. (2000). Xylanase pre and post-treatments of bleached pulps decrease absorption coefficient. J. Pulp pap. Sci., 26, 377-383.

22. Yang, S.Q.; Yan, G.; Jiang, Z.Q.; Lil, T.; Tian, H.M.; Wang, Y.Z. (2006). High-level of xylanase production by the Thermophilic Paecilomyces themophila $\mathrm{J} 18$ on wheat straw in solid-state fermentation. Biores. Technol., 97, 1794-1800. 